\title{
A Pedagogia Catequética de Álvaro Negromonte: Discursos ${ }^{1}$
}

\author{
Evelyn de Almeida Orlando
}

\begin{abstract}
Resumo
Este trabalho analisa a obra "Diretrizes Catequéticas" do padre Álvaro Negromonte como instrumento de apoio à coleção de catecismos do mesmo autor e tem por objetivo perceber, através do discurso do padre, as idéias que motivaram o projeto editorial da Coleção Monsenhor Negromonte. Metodologicamente, esta análise está assentada na Análise de Conteúdo, sem desconsiderar a articulação entre texto e história, muitas vezes evidenciada nos indícios que extrapolam os documentos e se fazem mais presentes nos sentidos e nos ecos que emanam dessa articulação do que na própria voz que encerra um texto escrito.
\end{abstract}

Palavras-Chave: Pedagogia Catequética. Diretrizes. Discursos

\section{Álvaro Negromonte’s Pedagogy Catequética: Speeches}

\begin{abstract}
This work analyzes the work "Diretrizes Catequéticas" of priest Álvaro Negromonte as support instrument to the collection of the same author's catechisms and he/she has for objective to notice through the priest's speech, the ideas that you/they motivated the project editorial of the Collection Monsignor Negromonte. The methodology of this analysis is seated in the Analysis of Content, without disrespecting the articulation between text and history, a lot of times evidenced in the indications that extrapolate the documents and they are done more presents in the senses and in the echoes that emanate of that articulation than in the own voice that contains a written text.
\end{abstract}

Keywords: Pedagogy Catequética. Guidelines. Speeches 
Este trabalho analisa a obra "Diretrizes Catequéticas" do padre Álvaro Negromonte como instrumento de apoio à coleção de catecismos do mesmo autor e tem por objetivo perceber, através do discurso do padre, as idéias que motivaram o projeto editorial da Coleção Monsenhor Negromonte. Publicada em 1938 pela Editora Vozes ${ }^{1}$, o livro é dividido da seguinte maneira: preâmbulo; o conceito de educação; como dar catecismo; necessidade do ensino religioso; o catecismo e a ação católica; o catecismo eficaz; o movimento renovador do catecismo e a pedagogia de Cristo, dispostos no índice ao final do texto.

Do ponto de vista material, o livro é uma brochura de 96 páginas que traz ao final, dispositivos técnicos que referenciam ainda três outras obras do padre, a saber: A pedagogia do catecismo, Manual de Religião e Doutrina Viva, todas publicadas pela Editora Vozes. Para cada um desses volumes, há o espaço de uma página, no qual é utilizado depoimento de diferentes jornais autorizando as obras. Nesse sentido, o texto "Diretrizes Catequéticas" é um documento $^{2}$ que emana vozes além daquelas que aparecem no próprio texto. Como projeto editorial, pode-se afirmar que é um instrumento de propaganda com uso de elementos refinados para oferecer outros produtos do autor e da editora ao público leitor. Considerando o discurso, que elementos técnicos encerram, a capa não deve ficar à margem de uma análise da obra, ainda que essa análise seja de conteúdo pelas interpretações e significados que ela suscita. A ilustração da capa traz uma figura de Jesus Cristo e seus discípulos, como aquele que os conduzia, que lhes dava as diretrizes. Remetendo ao título da obra, a ilustração enfatiza a necessidade de que as pessoas, mesmo fiéis, têm de liderança, de alguém que as conduza e lhes trace diretrizes por onde possam caminhar de forma segura, o que seria a função da obra.

Do ponto de vista do conteúdo, cada capítulo consiste em uma oração, palestra ou pronunciamento do padre em alguma ocasião importante em que se deteve a tratar da temática. No caso dos dois últimos capítulos, o padre explica para o público fluminense e mineiro (respectivamente nessa ordem) porque ele escreveu a Pedagogia do Catecismo em ocasiões que estes o saudaram coletivamente pelo seu trabalho.
Tratar das motivações que levaram à composição de uma obra com o próprio autor permite extrair deste alguns elementos que não foram tão evidenciados no texto escrito, já que o discurso oral é sempre mais fluido, mais descomprometido com o termo "documento". Por outro lado, ao transformar esse discurso em texto, não desconsidero os recortes que podem ter ocorrido pelo autor ou editor em nome de um produto final mais agradável e escorreito ao leitor. Não obstante esses recortes, um diálogo com o autor de uma obra é sempre elucidativo, o que fica refletido com mais clareza nos diferentes discursos que ele profere. Se o objeto em questão é a mesma obra, poderia o autor ter usado o mesmo discurso e justificar exatamente com esse argumento. Afeito às atividades que tinham como cerne a palavra falada, tais como discursos, palestras, conferências, seminários, aulas, o padre entende que o interlocutor é um elemento importante do discurso, ponto que não passou ao largo da sua perspicácia ao compor dois discursos diferenciados para o público fluminense e mineiro sobre a mesma questão.

Este estudo baseia-se metodologicamente na Análise de Conteúdo, sem desconsiderar a articulação entre texto e história, ou como propõe Ginzburg (1989), a relação entre texto e contexto, muitas vezes evidenciada nos indícios que extrapolam os documentos e se fazem mais presentes nos sentidos e nos ecos que emanam dessa articulação do que na própria voz que encerra um texto escrito.

\section{Por dentro da obra}

Já no preâmbulo, o autor destaca a necessidade do ensino da doutrina cristã como elemento fundamental para o futuro religioso e social do país. Segundo Manoel, a Igreja se propõe a dialogar com dois universos que compõem a história da humanidade, "um material, concreto, onde se realiza a história humana; outro abstrato, idealizado, para onde a história deverá levar os homens. Nesse contexto, a vontade humana e os atos decorrentes dela se constituem no ponto nodal e reforçam o que Elias propõe sobre o controle das pulsões ${ }^{3}$. 


\begin{abstract}
[...] tudo quanto o homem fez ou fará no concreto da história reflete sua opção ou ele age conforme os preceitos católicos e isso se reflete no equilíbrio social, ou ele age contra esses preceitos e gera o caos social. O ponto nodal é a vontade humana e os atos decorrentes dela [...]. Essa constatação invalida a convicção de que a Igreja ensina a passividade. Ela ensina, ao contrário, que o homem deve agir fortemente para direcionar sua história para um final feliz, para o reencontro com Deus e não para a perdição eterna (MANOEL, 2004, p.20)
\end{abstract}

Nessa perspectiva, a crença e o posicionamento que a Igreja adotou de considerar o mundo moderno mau, por ser fruto das teorias racionalistas e conseqüentemente levar ao abandono da doutrina cristã, levou esta a compreensão de que este mal deveria ser transformado pela ação da Igreja, mas não bastaria ampliar e fortalecer a esfera devocional e espiritual para reverter os efeitos da modernidade, essa estratégia seria o alicerce para uma sólida atuação sócio-política, visível nos empreendimentos da Ação Católica.

O catecismo, área de maior atuação e interesse do padre, é o elemento norteador das suas diretrizes. A ênfase na necessidade de tornar o ensino religioso mais atrativo, prendendo os alunos de forma espontânea, tocando-lhes o espírito para que venham a simpatizar com a religião. Entretanto, isso seria apenas o meio. A finalidade do catecismo é ponto nodal da educação religiosa, ou seja, fazer com que a criança viva o catecismo.

A essência da modernização do Ensino Religioso segundo o padre consiste exatamente em fazer valer essa prerrogativa, o que justifica a insistência em uma vida cristã prática. A publicação dessa obra também busca atender a essa necessidade, fornecendo elementos para uma prática cristã além de tentar suprir a lacuna existente em relação a obras que conheçam e tratem das necessidades nacionais. Por fim, as diretrizes catequéticas, conforme alude a ilustração da capa, remete às pegadas de Jesus Cristo, como a principal diretriz para a vida de um cristão, nas quais, segundo o autor, procurou se pautar para a construção dessa obra.

O primeiro capítulo é destinado a tratar do conceito católico de educação, chave para a compreensão da proposta pedagógica do padre e norteador da ação do educador católico, o qual sofre uma forte pressão do padre para que exerça a atividade de catequista conjuntamente à de professor. Não foi por acaso que Negromonte escolheu a colação de grau das alunas da Escola Normal de Belo Horizonte para tratar da temática, posto que, à época desse discurso ${ }^{4}$, ainda não havia sido publicada a sua Pedagogia do Catecismo. Os espaços destinados aos discursos eram legitimamente apropriados para proferir e inculcar a doutrina cristã. Tais mensagens eram acompanhadas da autoridade do agente eclesiástico que a proferia como um selo de autoridade e veracidade do seu conteúdo.

Negromonte estabelece uma relação de proximidade bastante estreita entre a educação e a filosofia. As doutrinas pedagógicas estão impregnadas das filosofias da vida e não é possível educar de forma diferente do que se pensa ${ }^{5}$. Para ele,

a filosofia dá o conceito da vida; a pedagogia dá o ideal da educação [...] Esta questão de ideal em coisas de educação é essencial. Mas o ideal da educação corresponde ao ideal da vida. Portanto, só uma concepção completa da vida pode fornecer um perfeito ideal educativo. Ora, esta filosofia da vida só quem tem a perfeita é a Igreja Católica; logo, só a Igreja Católica tem um ideal perfeito de educação (NEGROMONTE, 1938, p.10)

A finalidade da educação é tratada aqui tendo em vista a formação de um homem perfeito, o que requer uma visão do homem na sua totalidade. $\mathrm{O}$ conceito de homem para a Igreja compreende "corpo e alma, sentimento, inteligência e vontade; vida individual e social; vida interior e ad extra; vida terrena e eterna" (Negromonte, 1938, p.13) diferentemente da filosofia de Descartes que compreende o homem apenas pelo seu intelecto, ou pela vontade como pensou 
Schopenhauer, ou só natureza segundo Spencer, entre outros exemplos ilustrativos usados pelo padre.

A crítica às modernas pedagogias baseia-se fundamentalmente nesta questão chave para a Igreja. É preciso que se tenha clareza do ideal que norteia toda a prática pedagógica, o que segundo Negromonte as modernas pedagogias não são capazes de oferecer, ao contrário da Igreja. De acordo com o padre, o conhecimento dessa finalidade da educação "é o que de mais útil e necessário a Igreja pode oferecer". (NEGROMONTE, 1938, p.15). Partindo da premissa de que a verdadeira educação é aquela que prepara para a salvação eterna, e o único caminho para essa salvação é via Jesus Cristo, logo nos deparamos com a base que fundamenta a certeza da Igreja de que a verdadeira educação é a educação cristã. Segundo o papa Pio XI, na Encíclica Divini Illius Magistri, “A educação cristã abraça toda a extensão da vida humana, sensível, espiritual, intelectual e moral, individual, doméstica e social, para não diminuí-la de qualquer maneira, mas para elevar, regular e aperfeiçoar segundo os exemplos e doutrinas de Cristo" (1929). A educação assentada nessa base cristã asseguraria a formação de um homem de caráter fundamentado nos princípios do catolicismo. A proposta pedagógica do padre contraria a crença que se tem na imaterialidade dos fundamentos da Igreja. O padre considera e incentiva os diferentes tipos de educação: do corpo, das artes, das ciências, da tecnologia sem perder o foco de que a formação religiosa é a mais importante por conceber um sentido mais amplo e integral.

A palestra que compõe o segundo capítulo é lida às professoras de um Grupo Escolar de Belo Horizonte, em 1933; o autor retoma um dos pontos centrais na sua pedagogia do catecismo que é a necessidade de formação do professor, não somente do professor católico, mas também do professorado de modo geral e a este sobretudo e em particular por ter a dupla missão de ensinar as matérias e também o catecismo.

O professor não se pode satisfazer apenas e estritamente necessário para dar a aula [...] Só um largo e seguro conhecimento do assunto permite ao mestre discorrer com segurança e facilidade. E são intoleráveis as aulas em que o professor denuncia incerteza, hesitação, ausência de conhecimentos. Além do enfado que gera nos alunos, cria para si próprio uma situação de insegurança que termina por lhe tirar toda a autoridade [...] De modo que ao catequista não deve nem pode bastar a preparação remota, o conhecimento da matéria a ensinar. Ainda se requer, aqui mais que alhures, a preparação próxima de cada lição: saber o que vai dizer, como vai dizer, que exemplos vai dar, que comparações vai fazer, que histórias vai contar, que conclusão vai tirar, que aplicação fará a vida da criança, e até, se possível (e é possível pelo conhecimento das crianças e da psicologia infantil) prever as perguntas e preparar-lhes conveniente resposta (NEGROMONTE, 1938, p.25).

O ensino do catecismo requer, dessa forma, que seja ministrado de forma sistemática, com método, com vida, clareza, exatidão e solidez. Ainda assim, este andar desvinculado da prática não atingirá seu fim que é encaminhar o homem para Deus, levar a criança a praticar o bem e evitar o mal através da instrução dos dogmas e da moral católica. A instrução se constitui no catecismo apenas uma parte, segundo o padre, a menor e a mais fácil, pois o objetivo maior é fazer com que a criança viva os ensinamentos que aprendeu, coloque-os em prática. "O ensino do catecismo portanto, deve ser prático, eminentemente prático" (Negromonte, 1938, p.31). Cada plano de lição deve contar segundo as diretrizes com um lugar para a conclusão prática cuja catequista deverá mostrar a criança onde e como poderá aplicar os ensinamentos que aprendeu na aula.

Nesse ponto, o padre tece uma crítica às pedagogias modernas que acusam o ensino religioso de ser contrário à Escola Ativa, posto que o cerne do ensino religioso está em ministrar ensinamentos que se pratiquem, tendo em vista que, para a Igreja, o verdadeiro católico é o católico prático. 
Postulado da escola Nova é a atividade. Tanto que, em certo tempo, chamaramna de escola ativa. Ela quer a espontaneidade, o desenvolvimento das faculdades do aluno, a iniciativa. Há de ter o mestre um tato especial para fazer que o aluno trabalhe quase por si próprio, com gosto, aproveitando-se o mais possivel, realizando-se. E grande ciência é aproveitar as tendências do aluno [...].

Ora, se a escola Ativa não separa a Escola da vida, como se pode, em nome dessa escola, condenar e proscrever uma disciplina cuja essência é viver a doutrina que se aprende? Não, não se pode. O catecismo é a mais ativa de todas as disciplinas. Aí, mais do que em quaisquer outras, o ensino é dado para a vida, a verdadeira vida, para a qual esta existência terrena é apenas uma preparação e um caminho (NEGROMONTE, 1938, p. 86, 46).

O que constitui a terceira diretriz exposta pelo padre e autor da obra em questão consiste na necessidade do ensino religioso, discorrida em uma oração pronunciada às normalistas de Belo Horizonte, em 1934, no dia da colação de grau. Neste item, o padre acentua a necessidade do ensino religioso sobretudo para assegurar a manutenção do bem-estar social. Retomando a ausência de um ideal educativo, o padre alude à superioridade de uma pedagogia integral e finalista, a qual diz ao homem o fim para o qual existe, aponta-lhe a meta a atingir, ou seja, fixa no educando um ideal e envida todos os esforços para atingi-lo. Nisso consiste o projeto civilizatório católico, o qual encontra em pedagogos conceituados europeus o incentivo à cristianização do homem em prol da civilização: "o homem sem Deus e sem caridade não é um homem, mas um bárbaro" (PESTALOZZI apud NEGROMONTE, 1938, p. 36).

Apreciador da cultura francesa, "nação de cultura espiritual infinitamente maior que os Estados Unidos, a filha primogênita da Igreja" (NEGROMONTE, 1938, p.37), mas que obstinadamente insiste em manter a escola laica, exemplifica com dados estatísticos o crescimento da marginalidade, fruto do laicismo ${ }^{6}$. Os Estados Unidos não passam ao largo do seu olhar diagnosticador que aponta os males sociais nas nações tidas como berços de civilização como conseqüência de uma educação desvinculada da religião, cujos impulsos, os instintos, estado de barbárie são aflorados pela falta de moral.

Durante esse período em que se desencadeou a Revolução Francesa, o conceito de liberdade, um dos tripés que a sustentava, ganhou fôlego e criou fortes arestas no âmbito da religião, sobretudo da religião católica, que se organizou e reagiu contra os princípios da modernidade. Dessa organização, surgiu a corrente dos ultramontanos ${ }^{7}$, ala conservadora católica que apresenta como características fundamentais da reação antimoderna a rejeição a todo tipo de filosofia racionalista e à ciência moderna, a condenação às idéias liberais da democracia burguesa e o conseqüente reforço da idéia monárquica ${ }^{8}$, a condenação ao capitalismo e ao comunismo, o centralismo em Roma e na pessoa do Papa nas questões da política interna, a retomada das decisões fundamentais do Concílio de Trento (1545-1563), com destaque para aquelas que se referiam ao combate ao protestantismo e ao espiritismo? .

As estratégias dos programas da Ação Católica têm em vista recrutar o laicato para o serviço da Igreja. A quarta diretriz da obra consiste em discutir a relação entre catecismo e Ação Católica em um discurso proferido na Semana de Ação Católica em Belo Horizonte em 1935. Um dos pontos nevrálgicos da Ação Católica é a instrução religiosa e se falta capacitação para tal, a recomendação é que esta se faça urgente. $\mathrm{O}$ estudo do catecismo é recomendado a todos os membros da Ação Católica e pode ser realizado através de cursos regulares destinados especificamente para essa finalidade. Em uma nação impregnada pelas idéias liberais, a instrução religiosa se faz necessária tanto para adultos quanto para crianças, a fim de expurgar da sociedade os males trazidos pelo liberalismo.

O catecismo eficaz, quinta diretriz do padre, foi discutido também na Semana Catequística de São Luiz do Maranhão, por ocasião do centenário da fundação do Seminário. Incansavelmente, o padre 
Negromonte insiste na necessidade que acompanha os novos tempos de modernizar as práticas da catequese. Antes de fazer decorar é proposto que se ensine à criança, de maneira que esta entenda e assimile as doutrinas que estão lhe sendo postas. Recorrer à Psicologia Infantil é de grande valia, posto que o método que se utiliza para fazer com que uma criança compreenda algo é completamente diferente de como se trabalha com os adultos. A capacidade de abstração da criança não lhe perrmite assimilar com clareza algo que ela não conhece, nunca viu ou vivenciou. Por isso, o ensino deve partir do concreto, de coisas simples e avançar para as mais complexas tal como proposto pelas pedagogias ativas européias, em consonância com os fundamentos da Psicologia Infantil, para a qual é imperativo se considerar a idade e as capacidades de cada criança. Isso não repudia a prática de memorização; Negromonte reconhece na Pedagogia do Catecismo seus méritos e benefícios, com também reconhece os danos conseqüentes do seu mal uso quando, por exemplo, coloca-se a memorização à frente da compreensão.

As escolas novas trouxeram a compreensão de que aulas mais interessantes prendem o aluno, fazem-no amar o que aprende, além de facilitar o processo da aprendizagem. Negromonte se apropriou dessa concepção e incorporou esse mesmo discurso para as aulas de ensino religioso sob o influxo de gerar verdadeiros sentimentos cristãos nas crianças, fazendo com que a religião não fosse um fardo, mas algo desejoso de se conhecer e experimentar. Não obstante as suas particularidades, as pedagogias ativas se apóiam em uma base que coloca a criança no centro do processo do ensino-aprendizagem, para os quais convergem todos os movimentos e interesses em uma aula. Com uma dinâmica e uma lógica próprias, a criança passa a ser o centro de interesse do processo educativo. Tal compreensão não passa ao largo da Igreja Católica, a qual rompe com a concepção de criança como um ser passivo, sem características e necessidades próprias, uma espécie de adulto em miniatura, e como tal, sujeita aos mesmos tratamentos que este, e renova as suas práticas em relação aos seus pequenos discípulos. No discurso de Negromonte,

\begin{abstract}
é preciso constranger as crianças o menos possivel e dar-lhes o máximo de ensejos para exercerem sua insaciável atividade. Regalemos-lhes os sentidos, mostrando os quadros, deixando pegar; facilitemos-lhes os movimentos, não os conservando muito tempo na mesma posição, interrogando-os com freqüência e os ouvindo com agrado; atendamos-lhes às preferências fazendo rapidamente certos exercícios de que gostam menos e nos demorando nos que mais apreciam. Variemos, que a variedade deleita e repousa o espírito. Sejamos breves com os pequeninos que o ser breve agrada a toda a gente (NEGROMENTE, 1938, p.64).
\end{abstract}

As propostas didáticos propostas pela Escola Nova no Brasil foram lidas também pelos católicos que não se intimidaram em fazer uso delas com naturalidade de quem compreende um novo método melhor para trabalhar com a sua classe.

Entram aqui em jogo todos os meios didáticos de que se serve a Escola Nova, aplicando-se ao ensino religioso tudo o que se faz no ensino de outras disciplinas escolares. Não é apenas questão de êxito, mas de própria dignidade profissional, que tragamos para os nossos catecismos os processos pedagógicos que são a última conquista da ciência educacional (NEGROMONTE, 1938, p.64).

No influxo das palestras acerca do movimento renovador do catecismo que se instaurou com mais fôlego no Brasil a partir da década de 30 do século XX, Negromonte fala ao professorado fluminense ao receber deste uma homenagem pela sua obra Pedagogia do Catecismo. Nesse discurso, acentuou o estado de ignorância religiosa, considerado pela Igreja um dos piores males da modernidade em que se encontrava o povo e traçou um histórico de como se desenvolveu o movimento de renovação do ensino religioso. Dos minguados núcleos paroquiais, alcançava-se uma baixa freqüência com pouquíssimas 
chances de efetivarem uma formação religiosa. A via escolar, considerada a mais propícia, contava com um ambiente consideravelmente adverso no âmbito político, mas sobretudo no pedagógico. Os piores ataques ocorreram, segundo Negromonte, na esfera pedagógica, a qual contou com diferentes estratégias de resistência ao ensino religioso nas escolas públicas.

As dificuldades internas do campo diziam respeito à atualização e à renovação da escola. $\mathrm{O}$ ambiente passou a ser adaptado, ou sob medida, como denomina Edouard Claparède (1973), os processos e os métodos melhoraram, abandonando o antigo artificialismo pelo realismo da vida infantil. $O$ catecismo não estava acompanhando a nova pedagogia. A falta de preparo das professoras para adaptar o ensino religioso às novas propostas pedagógicas acentuava o distanciamento das demais matérias.

A crítica comum em relação aos católicos serem retrógrados em seus meios encontraram em Álvaro Negromonte a contestação de quem produziu, no Brasil, os subsídios necessários para equiparar o ensino religioso a todas as matérias escolares, proporcionando desde a releitura deste sob a influxo da escola Nova, através da coleção de catecismos que publicou assim como diversos outros textos, dentre eles, livros e artigos em periódicos, todos de caráter formativo até a formação das professoras e a preocupação em manter com estas uma espécie de formação continuada a qual se efetivou através do Boletim catequético fundado e dirigido por ele a fim de auxiliar o professorado em seu exercício contínuo em sala de aula, trazendo para o ensino religioso "as melhores conquistas da pedagogia"10(NEGROMONTE, 1938, p.77). Além disso, a prática tão questionada de memorização utilizada pelos católicos se constituía em um exercício corrente de todas as disciplinas, fosse ela religião, história, geografia ou aritmética antes da chamada Pedagogia Moderna ditar os rumos da educação. Saber de cor, confundia-se com saber e isso era um erro comum a todas as disciplinas. Dessa forma, à medida que as disciplinas escolares passaram por um processo de renovação, o ensino religioso que se propôs uma matéria escolar encontrou em algumas vozes, dentre elas, a do padre Negromonte, um interlocutor junto às idéias da Pedagogia Moderna sob égide do catolicismo.

O padre mostra, mais uma vez, a necessidade que se fazia premente de superar o caráter abstrato dessas aulas, modificando "a dureza impenetrável de sua linguagem abstrata, o arcaísmo desolante das suas perguntas e respostas, o apelo anti-pedagógico à memória pura, a apresentação desgraciosa de suas edições"11 (NEGROMONTE, 1938, p.74).

Nesse momento, surgem em âmbito nacional, as vozes de Leonel Franca, Alceu Amoroso Lima e Everardo Backheuser que serviram para iluminar e organizar o professorado católico para dar um sentido integral para a Escola Nova, embora os divulgadores desta tenham se esforçado para desvinculá-la da religião, ou como diz Negromonte, "deram-lhe uma feição irreligiosa" (1938, p.75). Nesse contexto, o movimento circular que impulsiona a cultura desencadeou, em quatro estados, uma organicidade em relação à temática da modernização da catequese, com o objetivo de dar à Escola Nova esse sentido integral, fundamento da pedagogia católica. Pernambuco se organizou com Jerônimo de Assunção, mas foi o padre Carlos Leôncio quem fez o movimento repercutir. Em São Paulo, a renovação girou em torno da figura da Irmã Lourença, no Ceará tomou vulto com Hélder Câmara e em Minas com o próprio Negromonte. Entretanto, o autor chama a atenção para já haver em Minas uma representação desse movimento na voz de Waleska Paixão ${ }^{12}$, um dos seus braços fortes em Minas Gerais.

Negromonte termina seu discurso às fluminenses dizendo que a Pedagogia do Catecismo foi mais um empreendimento do padre em favor das necessidades do professorado católico visando a renovação do ensino religioso.

Por ocasião de uma situação semelhante em Minas Gerais, cujo professorado católico mineiro também faz uma manifestação pela publicação da referida obra, o padre lança mão de um outro discurso no qual enfatiza a grandeza da capital mineira em desejar e manter o ensino religioso nas escolas públicas em um momento em que os conflitos no campo pedagógico em relação a essa temática estavam consideravelmente acentuados. "Parece que tinham identifi- 
cado religião e escola antiga, sem a elementar perspicácia para perceber que a Igreja só podia ensinar pelos métodos então correntes. Atribuía-se à Igreja um erro que era dos tempos. E com isso se fazia oposição surda ou pública à entrada do catecismo no regime escolar" (NEGROMONTE, 1938, p. 81). Ressaltou as dificuldades que as professoras enfrentaram com recursos didáticos tão pobres, impossibilitadas de realizar boas aulas, sempre ressaltando o esforço com o qual elas buscaram superar os obstáculos tendo o modelo pedagógico e método indutivo utilizado por Jesus Cristo como principal referência, o que é ilustrado com inúmeras passagens do Novo Testamento.

Por fim, o padre justifica a sua iniciativa, inserindo-se no bojo de um movimento que estava ocorrendo em algumas partes do país, mas ainda com pouca expressividade, que tinha por objetivo adaptar os progressos da ciência à doutrina de Cristo. Não obstante, nenhum outro representante empreendeu esforços tão grandes nesse projeto quanto o padre Negromonte que, reconhecendo a grandeza da idéia, visualizou as dificuldades, mas também os benefícios que esta traria ao projeto de recristianização da nação. Dotado de um capital social favorável, visível em seus agradecimentos, o padre evidencia o apoio recebido pelos poderes públicos ${ }^{13}$ e pelo professorado mineiro, os quais favoreceram-no, possibilitando o seu trabalho nas escolas públicas, sobretudo no Grupo Escolar Barão de Rio Branco, o qual se constituiu, ao mesmo tempo, sua escola e seu laboratório experimental da Pedagogia Moderna católica.

\section{Assim, ajudado eu vinha trabalhando. Os tempos requeriam certo aparato científico na apresentação do método pedagógico de que se serviu o Mestre Divino. Estudei a escola Nova à luz do Evangelho e o Evan- gelho à luz das conquistas pedagógicas des- te século. Reuni os estudos nestes dois li- $\operatorname{vros}^{14}$ (NEGROMONTE, 1938, p.90).}

O ascetismo cristão marca o fim do seu pronunciamento. Desprendido da presunção de um reconhecimento na terra por um trabalho realizado com os olhos voltados para o céu, o padre ilustra com essa atitude a teoria de Weber sobre o trabalho ascético e a interpretação de Bourdieu (1996) estabelecida a partir da compreensão da Igreja como instituição detentora de bens simbólicos que possui uma lógica própria de funcionamento e trata do ascetismo e da crença real que os agentes eclesiásticos depositados em seu trabalho. A homenagem então, embora não presumida, foi recebida pelo padre como agradecimento por seus amigos terem percebido, através da leitura de sua obra, a sua alma e as suas intenções pela grandeza de Deus e da Pátria. Ainda que a glória seja transferida para Deus ( sobretudo, por isso), não é possível desconsiderar que esse trabalho ascético confere ao padre ainda mais legitimidade e favorece ao associar a sua imagem a uma capacidade de abnegação capaz de se sacrificar em benefício da doutrina de Cristo. Essa imagem, de desinteresse e humildade associada a sua vocação declarada pelas coisas de Deus, asseguram para a Igreja e para o Estado a manutenção da ordem simbólica através de um discurso inconteste por seu caráter eminentemente santo.

\section{CONSIDERAÇÕES FINAIS}

Os discursos proferidos pelo padre Álvaro Negromonte constituíram documentos que contribuíram para escrever a história da renovação catequética no Brasil. A mensagem nas linhas e entrelinhas revelam a voz da Igreja em um momento no qual o grupo liberal, que se auto-representou como pioneiro do movimento da renovação educacional no país, tentava silenciá-la, postura que ficou evidenciada na escrita historiográfica sobre a presença católica nas discussões e projetos acerca da modernização do ensino no Brasil, a partir da década de 20.

Essa apropriação que a Igreja faz das teorias educacionais modernas, a necessidade de reconhecimento pela Instituição, mediante seu representantes do clero, de atualizar as sua práticas e exercer a atividade de ensino segundo as necessidades da modernidade. A educação é considerada neste artigo como uma prática cultural que se insere no movimento da história e se amolda às variações próprias da cultura, 
passível de circulação e apropriação pelos diferentes grupos que compõem uma sociedade.

Negromonte, percebendo o cenário que se configurava em torno da educação cristã e o que isso representava para a Igreja, chamou para si a responsabilidade de assegurar, através da prática educativa, a manutenção da ordem simbólica, através do ensino religioso, e não envidou esforços nesse empreendimento. Publicou livros, artigos, pronunciou conferências, palestras, organizou grupos de estudo, atuou em várias frentes para disseminar a doutrina católica, mas investiu, sobremaneira, com relevante perspicácia, na via mais segura e duradoura que é o impresso, o qual carrega em si uma missão educativa com vistas a um fim moralizador e civilizatório.

\section{Notas}

1 Esta obra foi publicada depois de "A Pedagogia do catecismo (1936)", "A Doutrina Viva" (1937) e "Manual de Religião" (1938).

2 Trato todos os livros da coleção como documentosmonumentos no sentido ampliado proposto por Jacques LeGoff (1984), um produto selecionado seja pelos historiadores ou pelas forças que operaram no desenvolvimento da humanidade em uma época histórica. Considero-os ao mesmo tempo um monumento que se instaurou na memória coletiva social, resultado do esforço das sociedades históricas para impor sua imagem ao futuro, o que justifica seu caráter duradouro. Como instrumento de poder, o estudo de um documento-monumento não deve desconsiderar o conjunto das relações econômicas, políticas, sociais, culturais e espirituais que permeou a sua construção e contribuiu para erigi-lo na história.

3 De acordo com Elias (1994), a vergonha e o embaraço são comportamentos inculcados em graus variados em sociedades industrializadas que refletem um certo pudor e polidez necessários ao padrão de civilização que se estabelece e passa a regular a vida social. O movimento de reformulação das necessidades humanas que se instaurou devido às transformações das relações entre os homens, o desenvolvimento tecnológico, em resposta ao novo padrão, não só determinou como consolidou novos hábitos sociais. As inclinações e tendências individuais, sobretudo as que dizem respeito à vida instintiva, sofreram um processo de modelagem muito maior do que o que acontecia na Idade Média e a Igreja se constituiu na representante mais indulgente da regulação dos instintos. Desde a Idade Média, os religiosos cultos se dedicaram à prática de redigir normas de comportamento que serviam de testemunho do padrão vigente da sociedade como De Institutione Novitarum, de Hugo de São Vítor; Disciplina Clericalis, de Petrus Alphonsi; e, dentre os versos de João Garland, 662 apareceram sob o título de Moral Scolorium às maneiras à mesa. Após o período da Renascença, começaram a surgir livros sobre comportamento social em geral. O sucesso que eles obtiveram em meio à sociedade aponta para a crescente importância do tema. Esses tipos de livro tinham a função de transmitir regras de civilidade para que as boas maneiras fossem estabelecidas como padrão social. No séc. XVIII, os clérigos tornaram-se os divulgadores dos costumes da corte. O controle das emoções e a formação disciplinada do comportamento apresentaram afinidades com tendências particulares do comportamento eclesiástico tradicional, o que resultou em uma civilidade amparada em um novo alicerce, religioso e cristão. A partir de então, a Igreja Católica passou a ser um dos mais importante órgãos de difusão dos comportamentos e estilos a partir dos estratos mais baixos da sociedade.

4 O discurso foi proferido para a turma de 1933 e a Pedagogia do catecismo só foi publicada em 1936.

5 Por essa razão, é fundamental para o padre tocar o pensamento e o espírito dos alunos e das professoras. Para que o ensino seja verdadeiro ou se aproxime daquela crença que Bourdieu se refere ao justificar a legitimidade das mensagens do corpo de agentes eclesiásticos. Eles crêem naquilo que pregam e essa verdade chega aos fiéis e os convence. Essa estratégia de auto-convencimento se dá pela formação do pensamento.

6 Fazendo uso da obra Les Crimes, Paris, Lethielleux, de Paul Barbier, da qual extrai os dados estatísti- 
cos de 1830 a 1900, a criminalidade se tornou cinco vezes maior. Este período de setenta anos, é subdividido e interpretado pelo padre da seguinte maneira: de 1830-1855, transcorreu vinte e cinco anos de um avanço progressivo na criminalidade, período que corresponde à Revolução e ao início de uma educação laica; de 1855-1875, passaram-se vinte anos de diminuição de crimes, período em que a lei Falloux trazia de novo a Igreja para a direção da educação; de 1875-1900, nota-se um progresso acentuado que corresponde ao período das definitivas laicizações. Vale salientar que antes de 1830, quando a escola francesa mantinha íntimas relações com a Igreja, a criminalidade era quase nula.

7 Segundo Manoel (2004) entende-se por Catolicismo ultramontano a autocompreensão da Igreja vigente entre o pontificado de Pio VII (1800-1823) a Leão XXIII (1958-1963). Esse período de 160 anos é composto por três momentos claramente distintos. $\mathrm{O}$ primeiro momento corresponde à consolidação da doutrina conservadora católica centrada mais no discurso do que na ação e compreende os pontificados de Pio VII (1800-1823) a Pio IX (1846-1878); o segundo momento, de Leão XIII (1878-1903) que se caracterizou por dar alguns passos em direção ao estabelecimento de uma política de intervenção católica na realidade; e o terceiro momento é o que gera mais controvérsias, pois compreende um período em que a Igreja adota a estratégia de conversão da doutrina em política, do discurso em práxis através do desenvolvimento que levaram aos programas da Ação Católica que culminou, por suas contradições, no Concílio Vaticano II. Esse último momento, apesar de ser englobado por muitos historiadores e estudiosos do campo da Filosofia da História como parte do ultramontanismo, parece-me pertinente considerar a questão posta por Manoel de ser este um período de transição do Catolicismo Ultramontano para um catolicismo mais progressista, onde muito do Ultramontanismo clássico era vivido na doutrina e na prática da Igreja, mas algumas práticas inovadoras como a presença do laicato, sua atuação junto à população, à modernização do ensino religioso, acabaram forçando mudanças doutrinárias e mesmo teológicas. Por essa razão, per- cebo a figura do padre que vive esse momento de transição com muita naturalidade, mantendo seu conservadorismo sem disfarces, mas por outro lado, aderindo a algumas medidas que as necessidades modernas foram impondo a fim de situar e impulsionar as ações da Igreja no tempo histórico.

8 Vale lembrar que a configuração hierárquica é um dos traços distintivos da Igreja Católica.

9 Esse combate resultou no Brasil na abertura de uma rede de colégios católicos voltados para o ensino secundário e superior visando a formação das elites que posteriormente viriam a dirigir o povo.

10 Obviamente essas melhores conquistas implicam um recorte, uma seleção do que era disponibilizado ao professorado católico. Vale lembrar que uma recomendação do padre tinha o selo de legitimidade atestada pela Igreja.

11 Nota-se a preocupação evidente com os dispositivos editoriais para oferecer o livro ao seu público. Além disso, o zelo pela estética é um traço característico da personalidade do padre, evidente também na construção da capela levantada na Sociedade Pestalozzi em Minas Gerais, conforme relata em sua carta à administradora da Fazenda do rosário, Sede da Sociedade.

12 Waleska Paixão, catequista, enfermeira, professora, foi diretora da Escola de Enfermagem Carlos Chagas, em Minas Gerais, por nove anos e da Escola de Enfermagem Ana Nery, no Rio de Janeiro, por dezesseis anos; é considerada por Álvaro Negromonte a pioneira nesse movimento de renovação catequética no Brasil, tendo começado seus trabalhos desde 1921, de forma incompreendida. A descoberta de Waleska Paixão é considerada por Negromonte uma de suas vitórias. Estabeleceu com ela uma parceria intelectual e organizaram grupos de trabalhos auxiliados por um núcleo de professoras nos quais desenvolveram cursos, aulas, divulgação de bibliografia, exposições catequéticas. Waleska Paixão foi colaboradora do Boletim Catequético fundado pelo padre Álvaro Negromonte e publicou diversas obras; dentre elas, Métodos e Programas e Formação da Consciência em seus Cadernos Catequéticos pela Editora Vozes em 1936 e 1940, respectivamente, livros que 
se tornaram referência nacional para a catequese brasileira.

13 Dentre as autoridades constituídas, encontravamse presentes o representante do Sr. Arcebispo, o Secretário de Educação do Estado de Minas Gerais, presidindo a mesa, e o Vigário Geral.

\section{Documentos Oficiais da Igreja}

Divini Illius Magistri: Carta Encíclica de Sua Santidade o Papa XI sobre a educação cristã da juventude em 31 de dezembro de 1929. São Paulo: Edições Paulinas, 1965

\section{Referências}

BOURDIEU, Pierre. Gênese e estrutura do campo religioso. In: BOURDIEU, Pierre. A Economia das trocas simbólicas. São Paulo, Perspectiva, 2005.

Razões Práticas: sobre a teoria da ação. Campinas/SP: Papirus, 1986.

CLAPARÈDE, Edouard. A Escola sob Medida. $3^{\text {a }}$ ed. Rio de Janeiro: Editora Fundo de Cultura, 1973

ELIAS, Norbert. O Processo Civilizador: Uma História dos costumes. Trad. Ruy Jungman, Jorge Zahar Editor: Rio de Janeiro, 1990.

GINZBURG, Carlo. Mitos, emblemas, sinais: morfologia e história. São Paulo: Companhia das Letras, 1989.

LE GOFF, Jaques. Documento/Monumento. In: Enciclopédia Einaudi. Vol.1. Memória-História. Lisboa: Imprensa Nacional-Casa da Moeda, 1984. p. 95-106.

MANOEL, Ivan A. O Pêndulo da História: tempo e eternidade no pensamento católico (1800-1960). Maringá: Editora da Universidade Estadual de Maringá, 2004.
NEGROMONTE, Álvaro. A Doutrina Viva: para o curso secundário. $2^{\mathrm{a}}$ ed. Petrópolis: Editora Vozes, 1941.

A Pedagogia do Catecismo. $2^{\mathrm{a}}$ ed. Petrópolis: Vozes, 1940.

Diretrizes catequéticas. Petrópolis: Editora Vozes, 1938.

Manual de Religião. $4^{\mathrm{a}}$ ed. Petrópolis: Editora Vozes, 1941.

Weber, Max. Ensaios de Sociologia. Tradução Waltensir Dutra. Rio de Janeiro: LTC Editora, 2002. p. 56 .

\section{Correspondências:}

Correspondência do padre Negromonte à Fazenda do Rosário-08/08/1945

\section{Documentos Eletrônicos:}

ALVES, Ana Paula Costa e SILVA JUNIOR, Osnir Claudiano da. Páginas de História da Enfermagem: o jubileu de ouro de uma obra (1951-2001). Esc. Anna Nery. [online]. ago. 2006, vol.10, no.2 [citado 14 Janeiro 2007], p.181-186. Disponível na World Wide Web: <http://www.portalbvsenf.eerp.usp.br/scielo.php? script=sci_arttext\&pid=S1414-81452006000200003 \&lng=pt\&nrm=iso >. ISSN 1414-8145.

\section{Documentos Oficiais da Igreja}

Divini Illius Magistri: Carta Encíclica de Sua Santidade o Papa XI sobre a educação cristã da juventude em 31 de dezembro de 1929. São Paulo: Edições Paulinas, 1965

\section{Sobre a Autora:}

Evelyn de Almeida Orlando é mestranda em Educação pela UFS e professora substituta do Departamento de História. 
